\title{
COMPLEXITY AND THE INTERNAL REVENUE CODE: THE PROBLEM OF THE MANAGEMENT OF TAX DETAIL
}

\author{
STANLEY S. SURREY*
}

This article proposes first to consider some causes of the present complexity of the federal tax system. In the light of these causes it will then examine whether, in the present state of our tax knowledge and, more important, of the tax policies that shape the development of substantive rules, there are means available to decrease that complexity. Finally, it will consider, against this background, steps that may enable us to manage the tax detail that "complexity" encompasses.

The term "complexity" is used here in a general sense to refer to the "complex technical structure" of the federal income, estate, and gift taxes. This phrase in turn refers to complex substantive tax rules with complex interrelationships, characterized by complex variations in the tax treatment of transactions often not differing greatly in substance or form, all of which are expressed in a complex statutory terminology and arrangement. While the substantive provisions produce, to a varying extent not necessarily dependent on the complexity of their formulation, computational difficulties for taxpayers and audit difficulties for the Internal Revenue Service, the focus of this discussion is not on those aspects. The discussion will largely be in terms of the income tax, though with different supporting illustrations much of what is said would also be applicable to the estate and gift taxes.

Causes of Complexity

\section{A. Unavoidable Causes of Complexity}

One basic explanation of the complexity we are considering is to be found in the fact that we have an income tax and that at the federal level it carries a tremendous load. The tax raises about sixty-five per cent of a federal budget of $\$ 200$ billion. Our federal tax system is thus really our income tax, and when we speak of the complexity of that system we are speaking of the complexity of the income tax. ${ }^{1}$ Certain attributes of an income tax, and especially one that must bear this load, are inevitably bound to create a very significant degree of complexity.

\footnotetext{
* Jeremiah Smith, Jr., Professor of Law, Harvard Law School.

1 The excises are relatively few in number, after the stripping down that occurred in the Excise Tax Reduction Act of 1965 , Pub. L. No. 89-44, 79 Stat. 136 (codified in scattered sections of the INT. REv. CoDE of 1954). Their complexities, mostly definitional and price measurement, affect a relatively few industries and taxpayers, primarily corporate. The estate and gift taxes affect only a small number of individuals, less than $5 \%$ of adult decedents. The payroll taxes have few problems associated with them, despite wide coverage. [The INT. Rev. CoDE of 1954 is hereinafter cited as CoDE.]
} 
This is not to say we would be better off it we had additional types of taxes at the federal level even though the addition resulted in our collecting proportionately less under the income tax than we do today. More taxes would mean more complexity not counterbalanced by any significant lessening in the complexity of the income tax resulting from this change alone. The income tax would still be with us to a very important degree and the factors associated with that tax that make for complexity would still remain-combined with all the complexities of a new mass tax. Thus, the addition of a sales tax on consumer goods, either in the single tax retail form or in the more complex multi-stage value added form, is not a path to lessened complexity in the federal tax system.

To return to the income tax-individual and corporate-we may examine some of the characteristics and attributes associated with its use in the United States that guarantee complexity.

\section{x. Pervasive Scope of the Tax}

The individual income tax is a mass tax in the United States-it has to be to raise the revenues we require from it. It therefore has very low exemptions in terms of population coverage. Even after the 1969 Reform Act's ${ }^{2}$ raising of the levels at which the tax starts to apply-a combination of increased minimum standard deduction and increased personal exemptions-the tax will still cover as taxpayers between eighty and ninety per cent of the adult population, starting with the very affluent and reaching down past the middle class and the skilled worker to the unskilled worker. ${ }^{3}$ Of necessity, this coverage sweeps under the tax an enormous variety and number of transactions for which a tax answer must be given-and given every year.

The corporate income tax has no exemptions and hence applies to all business in corporate form. Since "losses" are useful in the tax world-they may be carried forward or backward for a single corporation or sideways in a consolidated groupthe computations must be made for the unprofitable as well as the profitable corporations, year by year.

The income tax thus sweeps through most all of our economic and social life. If we reflect for a moment on the complexities and ramifications of that life in the United States-the world's largest economy, with a GNP greater than the European Common Market-then we are bound to recognize the complexities that will be developed through the very scope of the tax alone. To begin to think of all the ways people and businesses earn money, of all the ways in which businesses and activities are organized, of all the variations in which contracts, sales, employment,

\footnotetext{
${ }^{2}$ Tax Reform Act of 1969, Pub. L. No. 9r-172 (Dec. 30, 1969).

${ }^{3}$ When the transitions of the 1969 Act are completed, the tax will commence for a single person at $\$ 1750$, for a married couple at $\$ 2500$, and for a married couple with two children at \$4000. The minimum wage scale would provide a yearly income of $\$ 3000$ for a 40 -hour week and a fifty-week ycar (the average hours worked at this level are about 1500 , resulting in an income of $\$ 2250$ ).
} 
investments, and on and on can be structured, is only to begin to sense the vast range of questions that an income tax will generate. Moreover, the dynamism of the economy and its growth, together with a rising price level and a rapidly increasing population, constantly sweep new taxpayers into the system and at the same time propel existing taxpayers into higher brackets and often into a widening range of tax detail.

\section{The Measurement of Annual Net Income}

The modern income tax has four essential characteristics: (x) it applies to net income and not gross receipts; (2) it applies on a yearly basis; (3) it applies to the net income of particular taxable units, and the units must be precisely defined; and (4) for individuals it is applied at significantly progressive rates. Each of these characteristics generates requirements of definition and detail which are bound to produce complexities, especially when the tax is pervasive in coverage. The first two characteristics can be considered in the framework of the measurement of annual net income, or the base of the tax.

The concept of gross income-the first stage in the determination of net income, or taxable income-used under our income tax is quite broad, without the limiting factors sometimes found in other systems which require that the item to be taxable must be traceable to one of the sources of taxable income enumerated in the law. The breadth of the definition of gross income in the United States"all income from whatever source derived," with income largely being used in the sense of gain-eliminates some problems of application. At the same time, as the broad gross income concept gathers more and more receipts within the scope of the tax, refinements arise-in the treatment of annuities, in the treatment of cancellation of indebtedness, in the taxation of prizes or fellowships, in the taxation of employee fringe benefits, and so on. These refinements respecting the items are presumably more complex, though perhaps not, than the refinements necessary if the scope of gross income were less inclusive. The next stage, that of turning gross income into net income through the application of the expenses and expenditures involved in the earning of the income, requires a consideration of the broad panorama of the ways in which individuals, and even corporations, spend their funds and a determination of which ways are relevant for the income tax.

The annual nature of the tax requires this measurement to be made year after year. Moreover, many facets of this annual nature require that the measurement reflect an appropriate allocation of that income to the proper year. Both government and taxpayers have an acute sense of tax timing and the present worth of money in hand. At the same time, the United States has a well-developed accounting profession (partly because of the income tax) engaged also in measuring business profits over yearly time periods, so that the task for tax purposes is considerably eased. Still, the measurement for tax purposes presents some variations from business 
accounting. More important, many of the tax and accounting rules, verbally the same, involve a large range of generality and judgment. Given the value of a tax dollar presently paid as against one paid in the future, business and government appear inevitably to disagree on tax audits, though each is guided by accountants trained in the same principles and supposedly applying identical rules. ${ }^{4}$

This requirement for the measurement of net income, properly allocable to yearly time periods, is inherently a complex requirement. But this is not a criticism of the income tax. It is but one facet of why as a nation we regard the tax as the fairest form of taxation that the experts have yet developed for a modern society. Its inherent complexity is the other side of the coin of its equitable character.

\section{The Unit to be Taxed}

The income tax is on yearly net income-but whose net income? The tax thus demands a precise articulation of the taxpaying unit-and the reach of the unit once it is defined. Under the individual income tax, the problems cluster around the treatment of the family unit and the degree and manner of differentiation to be accorded among the various forms the unit may take. In brief, husband and wife are essentially treated as a tax unit, so that the tax burden of married couples is not dependent on the actual division of the family income between them. But the other members of the usual family unit, minor children, are not included within the tax unit, and are, in consequence, independent taxpayers. Hence the tax law is concerned with the actual division of the family income between parents and minor children. The existence of these taxpaying units in tax brackets usually lower than those of the parents is a standing invitation to tax-motivated transactions designed to shift the allocation of taxable income to the children while at the same time maintaining substantial control at the parental level over the income so shifted. This aspect is further complicated by the recognition of trusts, even while accumulating income for family beneficiaries, as separate, independent taxpayers. While some natural limits largely prevail on the extent to which the family of individuals can expand, there are no such limits on the proliferation of the family of trusts. Hence here again the tax law is forced to cope with intricate tax-inspired property arrangements utilizing trusts to reduce the family tax burden but not substantially altering the patterns of family control. Gradually we are moving in the direction of restricting the presence of the trust as a separate taxpayer, but each of the steps along this path has brought its share of complexities.

In the other direction, the particular nature of the tax treatment of husband

\footnotetext{
There is scope here for interesting research on the nature of the major disagreements that arise between our important corporations and the Internal Revenue Service, which collects millions in deficiencies from those corporations. The research should extend on a comparative basis to the United Kingdom, which places greater reliance on the accountants for the taxpayer and apparently does not have such disputes. But is its Inland Revenue underreacting and over-complacent?
} 
and wife as a unit, but splitting their total income between them, results in a tax burden on their total income which is less than that imposed on a single person with the same income. The discriminations this produces for classes of single persons whose economic positions approach that of the married couple have led to a treatment which differentiates among single persons. We thus have several "single" tax statuses-the single person, single person with dependent, single person who is head of a household, single person who is a surviving spouse maintaining a household-and then move on to the status of married couple and married couple with dependents and then on to the family with family trusts. The result is a complex pattern for the tax treatment of the family. Other patterns would make for a different set of complications, and, of course, since some unit of taxation must be decided upon to have a tax at all, some complexity is bound to result. Of course, the progressive rates under the individual income tax play a role in these complexities, as they also do in the use of the complexities involved in the measurement of net income and elsewhere; this factor will be discussed later.

In the corporate area, the critical determination of the unit is simpler, that of the single corporation. But since the modern business enterprise is composed often of a large number of related units, each in corporate form, the tax law has had to utilize the concept of the consolidated group and devise rules to govern the tax accounting for it. Further, since the business organization may take a variety of relationships between itself and its owners, in addition to that of the customary corporation and shareholder, such as mutual companies, cooperatives, associations, and joint ventures, the tax law must specify how each is to be treated. Then there are businesses whose manner of operation requires special rules, such as insurance companies. And as we pass beyond our geographical borders we enter into the problems of the corporation that goes abroad through the medium of a foreign subsidiary-problems that become marvelously intricate as the strands of foreign tax systems are raveled with those of our system.

Individuals may band together for business pursuits in ways other than the corporate form. Thus, the tax law must deal with the partnership form of enterprise, both to specify how it shall be fitted into the system and then, because it is treated differently from the corporate form, to determine the criteria of classification to apply when the partnership form in a particular situation closely resembles an association treated as a corporation.

In short, the ingenuity and diversification of business arrangements, necessary to solve the ever-shifting and varied facets of business and professional life, require in turn that the income tax provide an answer to what kind of tax unit is present, what income is to be allocated to it rather than to some other unit where each has contacts with the income in question, and how the income is to be measured-all questions of tax detail that are bound to present complications. 


\section{B. Some Particular Policies of Our Income Tax}

The foregoing characteristics of an income tax-inherent in its very natureclearly ensure a large degree of complexity in themselves, a complexity greatly enhanced by the size and diversity of the United States economy. But we must inquire whether certain basic policies which the United States pursues in applying its income tax make for greater or less complexity. These policies are not essential to an income tax, but rather represent choices seemingly open to governments using the modern income tax and regarding which, to some extent, different governments have chosen differently.

\section{Treatment of Capital Gains and Losses}

Perhaps the most important of these basic policies is the treatment of capital gains. As is well known, the United States grants a different and preferential treatment to items of income classified as capital gain. Hence, the income tax must identify "capital gains" and distinguish them from other income. Some might say this is a problem inherent in an income tax as such, since they argue that capital gains fall outside the gross income concept and hence that the identification of capital gains is implicit in the development of that concept. But most would agree that appreciation in the value of an asset falls within the contours of gross income. This being so, if this item of gross income is to be given preferential treatment, it must be capable of identification. But by now we have come to realize that there are no readily available tools outside the tax statute to which one can turn for a clear delineation of the capital gain concept. This being so, the income tax must develop its own definition of a "capital gain" to be given this preferential treatment. This is in itself a task of great difficulty. It must then, using that definition, classify all items and transactions as either capital gain or ordinary income, and pursue the classification through all the forms by which property may be owned and income earned.

Moreover, the United States has chosen not to tax appreciation in value as it currently occurs, through annual measurement of that appreciation even though not yet "realized" in cash or other forms by the taxpayer. It thus is not involved in the problems of measurement that such a system would at least produce. Instead, the appreciation or capital gain is only to be taxed when it is "realized" by the taxpayer. But this choice has brought with it another set of difficulties. As the passage of time increases the amount of appreciation in the asset relative to its cost, so that a larger and larger tax would be due if the gain were to be realized, the presence of that possible tax places a strain on the concept of realization. Should only a slight change in the form of the asset end the postponement of tax? If not, when does "slight" become "material," that is, material enough to warrant the tax. Should an involuntary sale end the postponement? A whole complex of classifications develops as this vein is pursued. Gains arising on certain transactions are not presently taxed-for example, reorganizations, exchanges of like kind, and 
so forth-but instead are deferred for recognition until a later transaction relating to the assets involved. Dispositions by gift and dispositions at death necessitate special treatment. Throughout, on the other side of the coin, losses are accorded different degrees of tax reduction capability depending on somewhat similar classifications and subclassifications.

As a consequence of all this, the treatment of capital gains and losses probably ranks at the top of the list of the separate causes of complexity in the income tax. But would a different treatment be helpful? No major industrial country has so far treated capital gains in the same fashion as ordinary income, so we cannot tell what the advantage in lessened complexity-which presumably would occur-may cost in economic effect or in other policies that would have to be pursued. And Canada, in its recent proposal to tax appreciation in value of publicly-held corporate stock every five years, ${ }^{5}$ is apparently the first country to move away from the concept of realization-we thus have yet to see what problems that course may involve. To be sure, a narrowing of the area now accorded capital gains treatment would be helpful, if the narrowing could be done fully without leaving residual enclaves. But, as we shall consider later, the Congress rarely follows the course of surgical sharpness, and most narrowings that are achieved carry with them new complexities.

It may also be, as our top rates continue to drop, and as the capital gain rate rises, that the strain on the capital gain classifications will be lessened as the differential in rates narrows. After all, we have come from a ninety-one per centtwenty-five per cent differential to a seventy per cent-36.5 per cent rate differential, ${ }^{6}$ which represents almost a fifty per cent reduction in the differential, and in the case of earned income, to a fifty per cent-36.5 per cent differential. We will have to see whether these significant changes will have their effect on complexity through a lessening of the tax drive to secure a capital gain classification for the transaction. And clearly, though the differential on realized gains has narrowed, we must remember it is still seventy per cent-zero per cent for appreciation on assets transferred at death. Until that differential is altered, we may indeed, in lessening the other differentials, be putting new strains on the "realization" concepts.

\section{Separation of Corporations and Shareholders}

The income tax applies both to individuals and corporations, so that corporate entities are taxpayers in the full sense of the word, though paying tax at rates different from those applicable to individuals. To this recognition of corporations as taxpayers, there is then added the recognition of dividends distributed to the individual shareholder-owners of the corporation as items of income includable in

\footnotetext{
${ }^{3}$ Canadian Ministry of Finance, Proposals for Tax Reform ch. 3 (I969).

- The $25 \%$ rate still exists for gains up to $\$ 50,000$ per family. The $36.5 \%$ rate includes the top $70 \%$ rate applied to half the gain plus the effect of the new $10 \%$ minimum tax where it applies.
} 
the gross income of those individuals without any allowance (except for the exclusion of $\$$ roo of dividends) for the presence of the corporation tax. This pattern of corporation-shareholder tax relationship-the so-called "double taxation" patternrequires for its development and application a considerable array of technical rules. When the capital gains concept is intermeshed with the operative rules governing the double taxation pattern, the range of complexity is vast indeed, and we have been exploring it fully.

The consequences of this separate treatment of corporation and shareholders are thus a cause of complexity. The resulting difficulties are compounded under our present tax by the desire in some situations to minimize the tax consequences arising from this separate treatment. It is the essence of this treatment that it provides essentially different results for business operation as a corporation on the one hand and as a partnership or sole proprietorship on the other. There are, of course, nontax differences that also exist between these forms of conducting business, and it could perhaps be said that for the most part the tax difference should be viewed as one more difference, once the basic decision has been made to have a tax difference. The trend, however, is increasingly in the opposite direction, with efforts to minimize the tax difference through permitting the choice of entity or non-entity tax treatment, whatever may be the non-tax form chosen to conduct the business enterprise. Some corporations are thus given the opportunity to remain corporations but for tax purposes to obtain close to noncorporate treatment-Subchapter $S$ corporations, investment trusts, and real estate investment trusts. (But an experiment to permit some partnerships in turn to elect corporate tax treatment has been dropped.) Since the particular tax rules differ in each case, the end result is an array of different tax patterns, each requiring its own technical implementation. Moreover, there appear to be no discernible rational premises which tell us when corporate entity treatment is to be required and when it is appropriate as a matter of tax policy to seek to devise rules whereby this or that corporation should be permitted to escape entity treatment?

This area has become more clouded by the fact that some of the proliferation of tax patterns is due to attempts to obtain for the partner and self-employed, primarily in the professions, the pension and profit plan tax deferment consequences and the

\footnotetext{
${ }^{7}$ Moreover, there are concepts underlying our corporation'-shareholder tax structure, which we have chosen or which have otherwise developed, that carry their own complications, such as the distinction at the corporate deduction level between interest and dividends and the rules associated with stock dividends. See, e.g., as to the latter, $\$ 421$ of the rg69 Act (amending CoDe $\$ 305$ ), restricting the use of "two classes of stock" to achieve capital gains for one group of shareholders in a corporation while providing regular dividends to a second group in the same corporation. This policy-which is necessary to protect the revenues under the present structure of the corporation-shareholder relationshipcontrasts with the ability of a shareholder to obtain capital gains through investing in a corporation accumulating its earnings and to obtain his annual dividends by investing in a different corporation which has a policy of distributing earnings.

On the matter of debt versus equity, see the developments in the new CODE $\$ \$ 279$ (use of debt in corporate acquisitions) \& 385 (classification of debt and equity).
} 
fringe benefits now accorded to owner-managers and other executives of corporations. The clouds become thicker when different taxpayer groups attempt to pull the concept in opposing directions to suit their diverse needs-as where the doctors seek to pin an "association" and "corporate" label on their joint enterprise but the real estate syndicates urge criteria that would leave their joint activities free of corporate classification.

At the other end of this particular spectrum are the complications caused by the devices needed to protect the Treasury against taxpayer utilization of the separate corporate entity unduly to escape individual income tax. This protection is today offered through the accumulated earnings tax, the personal holding company tax, the foreign personal holding company treatment, Subpart $F$ and other rules applicable to certain foreign investment companies and less developed country corporations, and generalized provisions such as sections 269 and $155^{\mathrm{I}}$ relating to corporate acquisitions with tax avoidance in mind. While these devices seem necessary complexities inherent in separate treatment itself, added strain results when they must be coordinated with the tax patterns adopted to neutralize separate treatment.

How much of this complexity is inherent in having an income tax and how much derives from the United States' choice of the separate treatment of corporations and shareholders as the path to be followed in handling the presence of the corporate form? There are other paths open-West Germany allows a deduction to the corporation for dividends distributed; France allows a credit to the shareholder against the shareholder tax for half of the corporate tax on a grossed-up dividend; Canada allows a credit against tax of twenty per cent of the dividend not grossed-up, but is now proposing the French approach for publicly-held corporations and a full integration approach for closely-held corporations.

Are any of these paths less complex-as to both substantive provisions and administration-than that traversed by the United States? All of them require a computation of the net income of the corporation, so that those complexities of the corporate tax remain. Comparative tax research does not appear to have answered the question posed, especially when it is linked to the relationship with capital gains treatment. Moreover, the national laboratories are not comparable, either in the extent to which tax questions come up (because of the differences in the scope of the business and investment sector and the sizes of the population) or in the degree of intensity with which governments and taxpayers pursue the answers. It is not enough to say that the path chosen by country $A$, as applied in country $A$, seems less complex than the United States approach, for the question remains whether that path applied in the United States in our economic and social setting, and with our highly sophisticated tax professionals, would still be less complex. Moreover, our present complexities have been the result of seeking answers to questions that did arise under our approach-the seemingly simpler past was simpler largely because the generalities had not yet been exposed as inadequate. Our present Code is more complex than the I939 Code-and of course the I9I3 law-because that 
Code answers questions which the earlier laws could not. So what may look simpler now in a different path for the treatment of the corporation and the shareholder may only be a reflection of the innocence of 1939, if not 1913, under our treatment. Again, this cannot be said positively for the needed research does not exist.

The thought presumably remains that any treatment of the corporation-shareholder relationship under an income tax will be inherently complex, with some.paths much thornier than others. We should not forget that there are important tax equity effects and economic consequences that follow with the choice taken, effects and consequences not yet fully articulated for us by the economists and investment community. Understanding of these results is veiled by the uncertainties still presented in the attempts to locate the incidence of the corporation tax. It is likely that these equity and economic aspects should govern the choice of the treatment to be followed rather than the matter of comparative complexity. Certainly the status quo, long in developing and understanding, should not be abandoned until it is reasonably clear there are real and important gains under a different approach. ${ }^{8}$

\section{The Rates of Tax and the Progressive Structure of Individual Rates}

Our income tax is imposed at relatively high rates, starting for individuals at fourteen per cent after the relatively low exemptions and rising to seventy per cent, and running from twenty-two per cent for the first $\$ 25,000$ of corporate income to forty-eight per cent on the balance. To be sure, the rates have been higher. Also, for some individuals the effective rates are less than the rate schedules would indicate, because of the many tax preferences that exist. And for individual earned income, absent tax preferences, the top marginal rate will be fifty per cent. But still these are high rates, in part reflecting the revenue burden the income tax bears. These rates compel at least reasonably precise answers to be given to the innumerable, endless questions generated by the broad coverage of the tax. If the Government is going to be a significant partner with every taxpayer in his business or occupation, the taxpayer will demand precise rules to ensure that such a partner does not overreach. Moreover, many a taxpayer will seek on his side to defeat such a partner whenever he can. The refuge of the wealthy in our modern society lies in the brains of their tax lawyers. But all of this in turn sets the stage for further rules on the part of the Government to see that taxpayers do not defeat its rights as a partner.

The individual rate structure reflects the progressive character of the income tax, an element of the tax that, by and large, commends it to most people as a

\footnotetext{
${ }^{8}$ Certain facets of our approach will also develop new aspects. Thus the change in the capital gains differential places corporate accumulation of income from securities on a tax rate parity with individual holding of the assets-67\% (48\% corporate rate plus $36.5 \%$ capital gain rate on the remaining $52 \%$ of the corporation's income) compared to $70 \%$ in the top bracket. But this, of course, assumes lifetime realization of the gain represented by the corporate accumulation-the zero capital gain rate at death still remains with us.
} 
"fair" tax, and thus one on which the Government can heavily rely for revenue. But some have urged a considerable abandonment of the progressive structure of the tax, by turning to a flat rate and a broader base leaving progression to the effect of the personal exemptions. There is talk in these quarters of a flat rate in the ten to twenty per cent range. A recent debate on this subject seemed to me to leave the advocates of a flat rate with by far the weaker case. ${ }^{2}$ On equity grounds, the path of continuous tax reform linked to a progressive rate structure topped by a fifty per cent effective rate on total income (not the fifty per cent marginal rate of the 1969 Act on earned income) seems by far the preferable course. ${ }^{10}$ As to complexity, Professor Bittker has contended that the flat rate/broad base approach has its own set of complexities. ${ }^{11}$ Moreover, such an approach seems but one horse in the conservative stable entry, the other being a national sales tax. The addition of another mass tax at the federal level, as stated earlier, is not a step in the direction of simplification.

Again, therefore, to the extent that a progressive individual rate structure policy results in complexities, those complexities are inherent in the type of income tax that commends itself to this country.

\section{The Presence of a Tax Expenditure Apparatus}

It has recently become evident that our present income tax system in reality embodies two functions. One is the application of an annual tax on net income whose purpose is to raise revenue, with a technical structure necessary to that application. It is this technical structure and its relationship to tax complexity that we have largely been considering. But alongside this regular income tax is an expenditure apparatus of considerable scope and magnitude which is cast in tax terms and is thus intermeshed with the regular income tax. This expenditure apparatus is designed, through tax benefits in the form of special exclusions, exemptions, deductions, credits, and deferrals under the regular income tax, to provide government financial assistance to a variety of business and social activities. For the most part these tax preferences are styled tax incentives and are intended through the assistance they offer to stimulate or assist action which the Congress considers appropriate. In a few cases the tax preferences are a means of relieving personal hardships.

Recent analyses of this expenditure apparatus provide us with a breakdown of its constituent elements and a quantification of the amounts expended. ${ }^{12}$ The

\footnotetext{
${ }^{\circ}$ C. Galvin \& B. Birtrer, The Income Tax: How Progressive Should It Bel (I969).

${ }^{10}$ The fairness of a top $50 \%$ effective rate on total income would presuppose at least income taxation of capital appreciation at death. It would be more appropriate, also, with the Canadian proposed approach of taxation every five years of the appreciation in the value of publicly-held stock. See Break, Integrating Corporate and Personal Income Taxes: The Carter Commission Proposals, in this symposium, p. 726 .

11 See Galvin \& Bitrker, supra note 9, at 33, 6r.

19 I 968 Treasury Sec'y ANN. ReP. 35-36, 322-40; Statement of Joseph W. Barr, Secretary of the
} 
range of activities aided and the tax preference techniques designed to provide the aid are wide and varied-natural resources (percentage depletion, intangible drilling expenses); construction (accelerated depreciation and perhaps even straightline depreciation); housing (even greater acceleration of depreciation, five-year amortization of rehabilitation expenditures, deductions for mortgage interest and real property taxes); philanthropy (charitable deduction, tax exempt status for certain organizations); farming (cash method of accounting, expensing of capital expenditures, capital gain treatment for certain assets held for sale); assistance to state and local governments (tax exempt interest, deduction for state and local taxes); investment (capital gains preference, \$1oo dividend exclusion); railroads (five-year amortization for railroad cars); pollution control (five-year amortization for pollution control facilities); health (medical expense deduction, exclusion of employer health benefits); education (charitable deduction, exclusion of scholarships and fellowships); assistance to the elderly (retirement credit, old age personal exemption, exclusion of Social Security payments), and so on. The over-all magnitude is somewhere in the range of $\$ 40$ billion to $\$ 50$ billion.

This tax expenditure apparatus is equal to about one-fourth of the regular federal budget. Moreover, it extends to every relevant budget classification except the space program, and even here the tax expenditures classified under commerce and transportation assist companies engaged in that program. A tax system that is required to contain an expenditure operation of this scope and magnitude is bound to be complex-it has in a sense all the complications that these programs would have if handled as direct expenditure programs in the regular budget. To be sure, the degree of complexity might vary somewhat item by item between the tax expenditure approach and the direct expenditure approach, sometimes probably being more, sometimes less, complex. But in totality, the existence of this expenditure apparatus is a tremendous force for complexity in the tax system viewed as a whole. In scanning the list of tax provisions involved in this apparatus we can certainly recognize item after item that has added its impact to the total complexity presented by our income tax structure. And much of the complexity of the 1969 Act derives from its wrestling with some of these existing tax incentives-for example, assistance to philanthropy, especially private foundations; farm activities; financial institutions; real estate and housing; the new minimum tax; capital gains-and, unfortunately, in adding new incentives, such as five-year amortization of housing rehabilitation, pollution control facilities, railroad cars, and mine safety equipment. ${ }^{13}$

Treasury, containing a "Comparison of Budget Outlays and Tax Expenditures By Function," Fiscal Year 1970, appearing in Hearings on the 1969 Economic Report of the President Before the loint Economic Comm., grst Cong., rst Sess. 8 (1969).

See also Bittker, Accounting for Federal Tax "Subsidies" in the National Budget, 22 NAT'L TAx J. 244 (x969); Surrey \& Hellmuth, The Tax Expenditure Budget-Responses to Professor Bittker, 22 NAT'L TAX J. 528 (1969).

${ }^{13}$ These tax preferences have caused complications for the accountants as well, as is evident for 
On the income side, these tax preferences establish in effect numerous schedular enclaves in what would otherwise be a unitary system. This special schedular treatment-such as that for tax exempt interest, for natural resource income, and for capital gains-makes it necessary to classify receipts involved among these compartments rather than simply calling them gross income. Moreover, in many situations these classifications made at one tax level must be traced through distributions to, or other connections made with, another tax level. Thus the separate subclassification of each gross income (and deduction) item in a partnership return must be carried through to the partners, that in a trust return carried through to the beneficiaries, and that in a Subchapter $S$ corporation carried through to the shareholders. It is clear that this required subclassification is a serious source of technical complication, which could be avoided if the unitary concept of gross income were not so seriously undercut by these schedular enclaves necessitated by the tax expenditures. On the deduction side for individuals, the availability of the so-called personal expense deductions reflecting the tax expenditures-for example, mortgage and other consumer interest, state and local taxes, medical expenses, charitable contributions, and casualty losses-greatly increases the amount of detail needed to reduce gross income to taxable income. The presence of the standard deduction is required to make this detail at all manageable. ${ }^{14}$

This is not the place to review the wisdom of the "tax expenditure-tax incentivetax relief for personal hardship" apparatus. ${ }^{15}$ It is clear that the vast bulk of the items involved in that apparatus could be handled as direct expenditure programs with the financial assistance, if it is still thought desirable, afforded through government grants, loans, interest subsidies, loan guarantees, services, and so on. It can indeed be argued that most of the items could be better, even far better, so handled. But so long as it remains national policy to handle the items through the tax system, we cannot blame our having an income tax for the ensuing tax complexities. $^{16}$

example in their struggles to find the proper accounting approach for the investment tax credit and the special bad debt reserves of financial institutions allowed under the income tax.

16 Professor Bittker has observed that the presence of these personal expense deductions eliminates questions that would otherwise arise-e.g., would a particular charitable contribution, or a particular medical expense for an accident at work, be a deductible business expense? GalviN \& BITTKER, supra note 9, at 64. But it seems clear that while the personal deductions may moot some questions which would require answers in their absence, they introduce a much broader range of other questions which would not arise in their absence.

${ }^{20}$ See Surrey, Tax Incentives As a Device for Implementing Government Policy: A Comparison With Direct Government Expenditures, 83 HARv. L. REv. 705 (I970). See also articles in Tax InstrTUTE of America, Smposium on Tax Incentives (to be published in 1970).

${ }^{10}$ Developments in the private pension area are an interesting example. Tax preferences are given to pension trust arrangements to further the national policy of encouraging the provision of financial security for old age, as a complement to Social Security legislation. In keeping with this policy, private pension plans, to qualify for the preference, must be nondiscriminatory in coverage and benefits. These requirements have produced a tax enclave rich in complexities, with its own corps of specialists. Recently, interest has turned to the desirability of strengthening the private pension system through adding requirements for vesting of pension benefits, adequate funding of vested benefits, and insurance of 
D. Tendency of the Complexity Inherent in an Income Tax-and a Tax Expenditure Apparatus-to Generate Still Further Complexity

The resulting complexities described above would be serious enough in themselves, but the seriousness of the effect is greatly heightened by the perhaps inevitable tendency of these complexities to generate still greater complexity.

\section{Every Important Tax Rule Generates Its Distorting Possibilities and Consequent Correction}

One cause of this self-generating complexity is that every important tax rule almost automatically produces its own tax distorting possibilities and consequent corrective provisions. This is a consequence of the interlocking and clashing of complex technical rules. Thus, the adoption of a carryover deduction for net operating losses immediately produces a trafficking in loss corporations as a consequence of placing the carryover loss rule in juxtaposition with the separate entity treatment of corporations. The result is a series of rules attempting to prevent this abuse of the carryover loss provisions. But these rules in turn bring about new frontiers of interpretation and maneuver, which are settled by new statutory rules, again creating new frontiers. The tax universe is indeed limitless, with no frontier ever providing a finite boundary. Additional examples can readily be found. The carryover loss illustration is repeated in the context of almost any corporate attribute possessing an intrinsic tax value whose utility can be transferred through transfer of the corporate stock or assets. In another field the separateness of trusts engenders the distortions resulting from attempts to divide a family fortune among multiple trusts and thus multiply the tax benefits accorded to a single trust. A similar resort to multiplication is found in the corporate area. The corporate reorganization provisions, a series of carefully composed and intricately meshed technical rules, give rise to endless maneuvers by taxpayers to combine facts and rules to produce results that the draftsman never visualized.

The aspect of complexity breeding complexity is in large part a result of the fact that our complicated tax rules are applicable to an enormously complex economic and legal system. Clearly, such a society both engenders and demands a complex tax system. However, the intricacy, the artificiality, and the arbitrary character of technical tax rules probably produce considerably more fertile breeding ground for still more complex rules than any other part of our legal system.

plans. These requirements could be engrafted on to the existing tax expenditure-pension provisions of the Tax Code. But they can also be structured as labor legislation outside of the tax laws, as are, for example, the laws relating to reporting by pension plans and certain responsibilities of trustees of those plans. The recent bills introduced on vesting, funding, and insurance take the latter course. The tax laws are kept from becoming more complex; labor legislation increases in complexity. See, e.g., Pension and Welfare Plans, Hearings Before the Subcomm. on Labor of the Senate Comm. on Labor and Public Welfare, 9ath Cong., 2d Sess. (1968). 


\section{The Difficulty of Perceiving the Contours of Problems of Structure}

The sheer complexity of the income tax, with its countless artificial rules and definitions, involves so many possible combinations of rules that efforts to study and evaluate the possible solutions to any single problem become enormously difficult. As a problem emerges, it appears to have a certain contour. Solutions are advanced to meet what seems to be the difficulty. There is indeed a tendency to jump too early in suggesting solutions, and these first solutions are often taxpayer-oriented. The relative simplicity of the solution, combined with its taxpayer orientation, sometimes makes for its adoption, usually with unfortunate results. Soon further study begins to disclose that the problem does not stand in isolation. It is connected by many strands with other difficulties. It is but a surface manifestation of deeper troubles. Its conceptual significance then becomes clouded as the links with other concepts begin to emerge. And soon those working on the problem perceive that they are grappling with a much wider and more complex problem whose ultimate solution will be far different from the almost pathetically inadequate answer first tendered.

Thus-as an example-in 1946 or so, the preferred stock dividend situation began to emerge as a problem, with its potentiality for the "bailout" of corporate earnings at capital gain rates. The Treasury Department began to deny rulings in this area. The response of the American Bar Association, Section of Taxation, in 1948 was to recommend a short section ${ }^{17}$ stating that the effect of the tax-free character of a preferred stock dividend was not lost merely because the stockholder sells or intends to sell his new stock, or that the new stock had sinking fund provisions fixed with reference to the marketability of the stock and was subject to redemption. The proposed section denied tax-free treatment if a plan existed to receive and sell a preferred stock dividend with an understanding that the stock would then be redeemed by the corporation. The problem in I948 seemed no more difficult than that. But a little later we began to perceive that the preferred stock bailout was only one illustration of a variety of bailout devices available to shareholders who desired to realize at capital gain rates on some of the earnings of the corporation while at the same time keeping their basic control of the corporation. There thus is the preferred stock bailout, the security bailout, the corporate division bailout, the partial liquidation bailout, the liquidation and reincorporation bailout, and perhaps others not as yet perceived. So we have sections $306,346,354,355$, and 356 , dealing with these bailout situations. But even now we are still dealing with them as if they were disparate and unrelated situations. And we are also beginning to perceive relationships of these matters to section $35 \mathrm{I}$ that had hitherto been unexplored.

In the corporate reorganization area, despite the existence of statutory provisions since I9I8, we have not yet seen the contours of the structural problems involved

\footnotetext{
${ }^{17}$ H.R. 4775,82 d Cong., Ist Sess. $\$$ I23 (1948).
} 
in many of the concepts, such as continuity of interest, the relationship of the reorganization rules to the corporate division rules, the implications for conglomerate mergers, and the like. The implications of the problems of multiple entities, such as multiple corporations and multiple trusts, are still being dealt with in legislation. ${ }^{19}$ We are still exploring the frontiers of distributions of stock dividends, in such situations as two classes of stock and certain preferred stock arrangements, ${ }^{10}$ and new frontiers are constantly being created by new financing arrangements. We are still picking our way through the ramifications of executive compensation provided through special stock arrangements, such as stock options and restricted stock. ${ }^{20}$ We have yet to formulate clearly the rules that distinguish debt from shareholder equity in a corporation and thin capitalization from appropriate capitalization. $^{21}$ All this is so because it is a heroic undertaking to pick a path through the maze of tax patterns, doctrinal concepts, and technical rules, and then to be able to evaluate what is a minor and arbitrary rule which can go either way in comparison to more fundamental issues where consistency with treatment and theory elsewhere requires an answer that goes only one way.

The remedy here lies in continued and extensive research into the problems of tax structure. The r950s saw considerable progress made, principally through the studies of the American Law Institute (ALI), which for the first time provided intensive and organized research directed toward an understanding of these structural problems. ${ }^{22}$ Thus, the structural problem of how to treat trusts and estates under an income tax were considered and steps toward a rational application of the existing substantive policies were made. Similar progress was made in the efforts to construct a rational structure for the treatment of partnerships. Considerable understanding of the ramifications involved in the operation of a separate tax on corporations combined with the capital gain-ordinary income distinction was achieved, along with a clearer conception of the basic premises at work in the reorganization area. The research also provided more knowledge on some rational standards of classification to support a capital gain policy that requires a separation of some gains, to be called capital gains and given preferential treatment, from all other gains and income.

Much of the ALI research found its way into the 1954 Code and hence present law. ${ }^{23}$ But we have not in recent years seen similar intensive research conducted

\footnotetext{
${ }^{18}$ Tax Reform Act of $1969, \$ \S 40 \mathrm{r}$ (codified in scattered sections of the CoDE), 33r, amending CODE $\S \S 66_{3}(\mathrm{~b})(2), 66_{5}-69,640 \mathrm{O}(\mathrm{b})$.

${ }^{10}$ Tax Reform Act of $\mathrm{x} 969, \$ 42 \mathrm{I}$, amending CODE $\$ 305$; see note 7 supra.

${ }^{20}$ Tax Reform Act of $1969, \S 32 \mathrm{I}$, adding CODE $\$ 83$, and amending CODE $\$ \$ 402(\mathrm{~b}), 403$ (c), 404(a) (5).

21 Tax Reform Act of $1969, \S 415$, adding CoDE $\$ 385$.

${ }^{22}$ See ALI Fed. Income Tax Stat. vols. I \& II (Feb. 1954 Draft); AII, Income Tax Problems of Corporations and Shareholders (1958); AlI, Definitional Problems in Capital Gains Taxation (1960). See also Advisory Group Recommendations on Subchapter $C, J$ and $K$ of the Internal Reventue Code, Hearings Before the House Comm. on Ways and Means, 86th Cong., Ist Sess. (I959).

${ }^{23}$ Although a good part of the research found its way into the Revenue Code of 1954, for a varicty of reasons the research was not utilized in a manner designed to achieve its maximum potential.
} 
on structural problems. Certainly there has now been sufficient experience with the structural changes instituted in the 1954 Code and subsequent related legislation to warrant that research. Only through such research can we uncover and identify the faults of the basic substantive policies which are responsible for some of the existing complexities and difficulties. Only then are we in a position to understand the choices that must be made between retaining those substantive policies and doing the best we can to live with the complexities or seeking to alter those policies if we desire fewer complexities. ${ }^{24}$

\section{E. Aspects of the Process of Developing Tax Policy}

The foregoing discussion has indicated some of the causes for complexity that grow out of the technical structure of our income tax. We can now turn from that structure to the process by which it is developed, to consider whether various facets of that process are factors contributing to the complexities of the technical structure. In a broad sense, we will be discussing the political process by which tax policy is formulated and administered. The consideration will be largely in outline form, for much can, and should, be written on this process if we are to understand better the workings of our tax system.

\section{The Legislative-Executive Relationship}

The United States does not have a parliamentary government structure. As a

While the tremendous effort that went into the Revenue Code of 1954 was in considerable part an instance of wasted opportunities and, in some cases, of ground lost, still some advancement occurred. The 1954 Code is vastly more complicated than the 1939 Code. But those who decry its complexity and yearn for a return to the "simple" I939 Code really miss the underlying reason for this development. The 1954 Code is more complicated because it examines and answers many structural problems that were left unanswered in the 1939 Code, as in the case of trusts, partnerships, and corporate distributions. Thus, the 1939 Code left unanswered the basic question of whether the treatment of partnership situations was to develop along entity or aggregate lines. There was thus a wide gap in the I939 Code with respect to the tax rules applicable to the partnership form of doing business-a gap which related to many hundreds of thousands of taxpayers. There was another gap in the application of the conduit concept underlying the treatment of trusts. In the corporate distribution area, it was beginning to be recognized that the 1939 Code general phrase "essentially equivalent to a dividend" was too frail to bear the weight of the capital gain-ordinary income pressure, and more particularization was needed.

${ }^{24}$ Thus, one chief result of the ALI tax research was the disclosure of how pervasive were the difficulties caused by the capital gain-ordinary income dichotomy. The ALI I954 Draft Statute vigorously pursued the problems of structure in the corporate distribution and partnership areas, attempting to achieve the best technical structure possible within the confines of their basic substantive policies. Without question it was the need to produce workable rules consistent with the capital gain-ordinary income classification that was at the root of those provisions which exhibited the greatest complexity. The technical problems in the partnership area would be considerably less troublesome if the capital gain differential did not exist. The other principal problem in the partnership area, that of maintaining identification at the partner level of those items of income and deduction of the partnership which are specially treated by the Code, is a reflection of the difficulties caused by the tax expenditure apparatus and the resulting schedular enclaves that run throughout our Code. Here again, rigorous technical analysis of the problems of structure permitted assessment of the causes of complexity. In the corporation distribution and related areas, the real complexities in the sections relating to corporate divisions, partial liquidations, stock redemptions, collapsible corporations, reorganizations, and so on, are traceable to the capital gain issue. But all this becomes clear only after the task of rigorous technical analysis under existing substantive policies has been undertaken. 
result, the executive branch cannot control the shaping of the income tax structure. Indeed, the primary voice in tax legislation is legislative, that of the Congress. One suspects that a parliamentary government able to control the shaping of intricate legislative programs should be able to devise a structurally more coherent and to that extent less complex tax system than the United States system. But here also comparative research does not provide an answer. What we do know is that, under our legislative system, the pulling and hauling between Executive and Congress, between the tax committees and the parent legislative bodies, between the House and Senate, between lobbyists for the private sector and the lobbyists for the Executive, between one group of private lobbyists and another group, and so on, can yield ultimate legislative decisions which provide disorderly patterns of tax structure. There is no commanding voice to bring order out of these many and often simultaneous struggles. The result is bound to be more rather than less complexity in a tax system.

\section{Compromises and Detours in Legislative Decisions}

One way of seeing the consequence of this legislative method for developing tax policy, with all its varied power struggles, is to focus on the nature of the solutions that emerge as important and contested tax changes work through the Congress. Very often, and more likely the more important the problem, the resulting solution is a compromise. In a sense, many of the legislative struggles end in cease-fire agreements which accept as solutions the legislative battlefield lines that happen to emerge at a particular point in the disputes. Cease-fire arrangements rarely mean neat, orderly, and logical boundary lines. And so it is with tax disputes and their solutions which become a part of our evolving tax structure.

A glance at the decisions in tax reform efforts is illustrative. Whether it be the entertainment expenses and foreign income changes in 1962 , the stock option and personal holding changes in 1964 , or the capital gains, farm, foundation, real estate, and minimum tax disputes in 1969 , the final result was a compromise more complicated than the prior law or the solution initially offered by those seeking change. The minimum tax itself is a compromise between the competing pulls of the tax expenditure apparatus and tax fairness; it recognizes the existence of the tax preferences under that apparatus but states that collectively those preferences (that is, those covered under the minimum tax) cannot reduce the tax liability of a particular taxpayer below a minimum level.

Given the resistance to tax reform, the history of many a tax preference is that of strongly waged legislative campaigns to retain the preference, with each legislative battle marked by a slow retreat to a new front. Each retreat brings a new complexity. As examples, consider the efforts over the years to retain the benefits of multiple corporations, perhaps finally ended in the 1969 Act, or those to retain the advantages of accumulation trusts. These aspects of the formulation of legislative 
policy underscore the need for careful research before an important change is made, for mistakes are rarely retrieved either quickly or simply. Thus the failure in I954 adequately to safeguard the newly adopted accelerated depreciation provision from abuse was a major defect that has plagued the tax structure ever since, and has accounted for many a complexity through subsequent efforts by the Treasury to retrieve ground that never should have been lost in the first place.

The consequence of increased complexity is obvious. We must remember that no taxpayer group ever rejects a new tax preference on the ground it is complex. Nor does a group seeking to retain an existing tax preference reject a compromise solution because of its complexity and retreat to a simpler but less favorable result. Nor can the Treasury, when the chips are down, also reject a solution on grounds of complexity if the alternative really means a serious widening of a tax unfairness or unwarranted preference. In essence, all parties to the legislative struggles place substantive positions and results ahead of concerns over complexity. Moreover, the more intense the struggle, the less likely are the parties involved to make the minor concessions here and there that could mean a less complex solution. It is hard for technicians to deal with these aspects of tax structure when the battlefield fire is intense.

Even in less important or less prominent tax changes, when there often is general agreement on the change and its contours, the particular problem of a particular member of Congress may often have to be met if the legislation is to move along, even though the solution means a break in the logical tax pattern which the change seeks. Thus, many a queer twist in a tax boundary line, many a sudden turn or detour from the expected development-all of which means an added complicationis explainable only in the light of such an accommodation. The legislative commentaries that accompany our statutes are usually not explicit on such a background, and so many a tax practitioner and many. a judge must wrestle with the aberration and often end by reading into it a purpose or meaning foreign to its origin. As a result, the original complication begins to breed further complexity as the unintended doctrine develops.

In this setting, efforts at "base broadening" to achieve less complexity are not likely to accomplish that goal. The result, as stated above, may in the end meanand has meant-more complexity. But such efforts are important for their effect on tax equity and, in the trade-off between the two, tax equity should be given the emphasis.

\section{Accessibility of Legislative Change}

Under our legislative system, taxpayers-that is, some taxpayers-because of sophistication, contacts, mere constituent status, or whatever the particular nexus, do have access to the legislature to obtain a change in the tax laws, and far greater access than in parliamentary countries. Hence, when tax provisions pinch or thwart 
or create obstacles to a particular transaction or arrangement, or suddenly cloud a completed event, increasingly the tax advisors suggest as the solution a resort to the Congress to "change the law." So the course of legislative change is pursued, rather than that of different planning, judicial recourse, or an acceptance of a secondbest alternative. If the Congress responds favorably, and it often does, the usual result is one more complication added to the tax structure.

\section{Defects in Administration}

Some of our most serious legislative problems and the resulting complexities arising from their solution have developed from defects in administration. At some point the wrong turn was taken in administrative interpretation and decision. The cause may range from a weakness of personnel, or an error of judgment on the particular issue, to an understandable failure to appreciate the later consequences of what seemed an obvious or adequate solution to the problem then before the administration. But whatever the cause, the correction needed when the full effect of the wrong turn is perceived is usually a complex statutory provision more complicated than would have been the developments under a different administrative decision. Or perhaps the complications would exist but would have remained at the administrative level for shaping and handling rather than being shifted to the legislative level. Some examples, not inclusive nor necessarily chosen in terms of importance, are the initial regulations or rulings permitting the cash method of accounting for all farmers and the expensing of livestock raising costs and development costs of orchards and ranches; allowing the current deduction of intangible drilling expenses of oil wells; granting a tax-free status to the interest on industrial development bonds; granting a tax-free status to the organization of "swap funds"; permitting a two-classes-of-stock situation to survive under section 305; excluding Social Security payments from income; excluding group term life insurance from income; according an erroneous treatment to restricted stock arrangements; and permitting an artificial and excessive bad debt reserve for commerical banks.

Of comparable importance in many cases is the inability, for one reason or another, of the administrative agency to move affirmatively to correct its own errors once they are revealed. The result forces legislative correction when administrative correction would suffice. It may well be that the administrative correction would in the end have to run a legislative gauntlet and the result may still be a statutory provision. But it may not. Akin to this inability is the failure at times to recognize potential tax avoidance in the making in a particular area as more venturesome taxpayers or their advisors begin to probe an apparent weakness in a statutory provision. Here alert administrative response, to protect the statutory provision and assert that the weakness does not exist, may well ward off the probers and make unnecessary a statutory change to correct the exploitation that would otherwise have occurred. 


\section{Judicial System for the Consideration of Tax Cases}

The present judicial system for the consideration of tax cases seems prima facie to work in the direction of more complexity in our tax law. Prima facie, it hardly seems efficient to have an elaborate Tax Court procedure alongside a District Court system and a Court of Claims forum as well; or to have Tax Court decisions spreading out for appellate review to eleven Courts of Appeals; or to have complex civil tax issues decided by juries; or to have so much turn on the deficiency as against the refund procedure; and so on. The many avenues open under this judicial system would seem, through the diversity of responses they afford, especially if the government's litigation pattern tends to be opportunistic, to make for a greater need for legislative correction or response than would a more unified and less elaborate structure. Of course, under the latter structure, a wrong answer once initially given may perhaps mean more often a wrong answer in the end; whereas the multiplicity of judicial expressions possible under the present system may in the end, albeit a long time, produce correction through that diversity. In the past, study has been given, in spurts, to the existing system; and methods of correction have been suggested. But more attention and research are required before we can say that the existing system is the most efficient, all things considered, or before we can say that while inefficient its protection by the status quo will prove unyielding to change.

\section{F. Factors Lessening the Extent of Complexity}

Everything in our income tax system is not a force working for more and more complexity, though the above discussion certainly makes it appear that way. There are factors that move in the opposite direction and operate to lessen the extent of the complexities that would otherwise result from the causes we have been considering. The following factors are illustrative and not an exhaustive listing, and more thought needs to be given to this aspect.

\section{Administrative Devices}

A very large variety of essentially administrative devices keeps the income tax manageable in its mass application despite the complexity of its statutory structure. Among these are the graduated withholding at source on wages and salaries; the use of the standard deduction to submerge many of the problems involved in the grant of deductions for personal expenses; and the constant improvement in the return forms and instructions generally applicable. Moreover, we must keep the matter of complexity in perspective. We do administer a mass income tax under a system of voluntary self-assessment and with an Internal Revenue Service force far smaller in number in relation to the tax coverage and revenue involved than other industrialized countries. We are presumably also ahead of those countries in the use of automatic data processing and computerized operations. In this sense our tax system is not too complex over-all. It has required the development of taxpayer- 
assistance businesses for return filing. And there presumably are unfairnesses in the mass administration that are traceable to complexity. Many of the elderly apparently do not obtain the tax relief they are granted because of the complexities with which that relief is structured. Nor have we paid sufficient attention to those close to poverty levels to see how the tax system is working for them. But all in all, it is a successful mass operation of a complex tax structure. In this respect, much, but by no means all, of the complexity we have been discussing under the individual income tax grows from the problems of applying the income tax to the affairs of the relatively well-off sector of our society, and vice versa. The revenue involved in that application is large, however: thirty-three per cent of the tax comes from adjusted gross incomes over $\$ 20,000$ but they account for only 3.2 per cent of the returns; and forty-three per cent comes from those over $\$ 15,000$, with seven per cent of the returns.

At this end of the taxpayer scale and for the corporate area, the ruling procedure of the Service helps to provide some certainty amidst the imponderables of unresolved issues and ambiguities of statutory interpretation. The Service in many instances will by ruling resolve the issue for the particular taxpayer involved and may later generalize its answer so that other taxpayers are also informed.

\section{Judicial Attitudes Respecting Statutory Interpretation}

The courts in deciding cases under the Internal Revenue Code have for some time rejected a literal application of the statutory language in favor of a general anti-tax-avoidance approach which seeks to apply the Code provisions in keeping with the Congressional purpose as divined by the courts. The "business purpose" doctrine is a basic illustration. While the doctrine has many shades of meaning and application, it nevertheless is clearly understood by lawyers to stand as a barrier to those tax avoidance schemes that must depend for their validity only on a literal application of the statutory words. The doctrine requires that a justification must also be furnished of a motivation or rationale for the transaction in addition to its conformance with statutory language. ${ }^{25}$ The result over-all makes for a less complicated statute. Statutory safeguards need not be provided every time an ingenious taxpayer or his advisor thinks he sees a way to manipulate the statutory language

\footnotetext{
${ }^{25}$ There are aspects of the "business purpose" doctrine that seem to invite interesting research. Just what is a court saying when, after hearing counsel urge on it the enumerated "business purposes" of the taxpayer, it announces that those were not the purposes for the transaction, or were not the motivating purposes, or did not appear to make business sense under the circumstances, and hence cannot be accepted as purposes? Just what is counsel doing when he urges those purposes in explanation of the transaction? What is counsel's role in discovering business purposes for the transaction when it is being planned or after it has been consummated, or in leading the client to "discover" those purposes for himself?

An interesting area of research would be to compare the present case law with that of earlier periods to see whether there is a trend to a lessened judicial willingness to cope with new tax avoidance devices, and if so whether the declining willingness to fill the statutory gaps-and a corresponding increase in decisions to leave the matter to the Congress to resolve-stems in any way from the increased particularity and complexity of the statutory material.
} 
in a manner foreign to the purpose of the provision. Some things can thus be left unsaid, either originally when the provision is drafted or, more likely, when its potentialities for tax avoidance if the provision is literally applied are discovered, especially if administration is vigilant and energetic.

\section{Trend to Reduce Issues of Tax Timing}

The legislative trend in the tax accounting area is steadily to reduce the possibility of issues arising over tax timing. A continued resort to the transactional approach, as against a rigid compartmentation of tax years, has made unnecessary or unprofitable controversy over many questions of tax timing. Examples are sections I3II-I4 relating to removal of the statute of limitations and other barriers to adjustment when inconsistent positions in the treatment of an item are taken, section I34I providing a transactional adjustment when an item of income must be returned by a taxpayer, and section $48 \mathrm{r}$ relating to facilitating adjustments occasioned by changes in methods of accounting. Other measures lessen the importance of timing issues through a lengthening of the statute of limitations, as in the case of stock losses and bad debts, or by prescribing when certain losses shall be considered as having occurred, as in the case of war losses. While many of these special sections are in themselves intricate statutory mechanisms and the transactional approach has, unfortunately, not been fully articulated in the statute, their presence does work for an over-all lessening of complexity as respects the aspect of tax timing.

We have in recent years moved considerably further along this path of eliminating tax timing issues by adopting in 1964 five-year averaging for individuals and in 1969 extending its scope and lessening its intricacy. ${ }^{26}$ The future should see further experimentation along these lines as we gain knowledge-or accept the knowledge that academic research already may offer-of the advantages of a more extensive averaging system and gain experience in administering such a system, especially through the use of computers.

\section{II}

\section{The Appropriate Internal Revenue Code-Highiy Detailed or Generaltzed?}

It is clear from the above discussion that whatever substantive policies we adopt and whatever the structural rules we devise to implement those policies, the income tax statutory provisions will be among the most complex in the United States Code. This being so, more thought is needed on whether the over-all pattern of the income tax statute can be improved so as to keep that complexity within reasonable bounds.

Certainly it would seem that a logical and coherent statutory framework is here an essential. A properly organized statute, with intelligent classification and grouping

\footnotetext{
${ }^{20}$ Tax Reform Act of $1969, \S 31 \mathrm{x}$, amending CODE $\$ \$ 1301-04,65 \mathrm{II}(\mathrm{d})(2)(B)$ (II). This new averaging provision permitted the elimination of earlier ad hoc averaging for lawyers, authors, recipients of back pay, and others in this situation.
} 
of its sections, obviously aids in achieving a sense of order and perspective. The r954 Code is an improvement in this respect; though while it built upon the ALI Draft Statute, it did not achieve the full potential which that draft offered. ${ }^{27}$ As we move from the over-all Code framework to the separate provisions themselves, an important if not essential contribution to clarity is a logical and coherent statutory solution to the problems of structure. The sections and provisions carrying the rules for the treatment of a given area must possess an internal consistency, so that the framework and inner logic of the statutory solution can be grasped. In turn, the treatment accorded one area should be consistent with that in a related area, so that the larger structure will exhibit a harmonious and integrated pattern. The drafting techniques utilized must make this structural framework clear, so that its order and logic can be perceived in full rather than hopelessly submerged in detail.

If all this is done, the perspective obtained will enable us to apply the statute in an intelligent way when we must use it to solve the questions of structure and detail that were unforeseen when the provisions were first drafted. With such a statutory formulation we can have some hope that the process of interpretation and application will permit the structure to develop and grow along orderly, predictable lines. But here again, a logical and coherent statutory formulation is impossible without a base of hard technical research delineating the structural problems and providing the blueprints for the draftsmen. For no draftsman is any better in the end than the quality of the research that preceded the final act of putting its results into statutory language. ${ }^{28}$

We must, however, move further than these general observations to consider the present style and manner of tax law drafting. It has been urged by some that the chief source of complexity in the income tax, and the tax system generally, is the highly detailed, intricately structured drafting that permeates much of the present Code. In this view, a generalized "simpler" statute would thus operate to reduce the present complexity. Undoubtedly our Code provisions, especially those since x954, are following this involved, intricate pattern. Part of the reason is haste, and the drafting style may indeed be that best suited to the conditions under which the

\footnotetext{
${ }^{27}$ See Surrey \& Warren, The Income Tax Project of the American Law Institute: Gross Income, Deductions, Accounting, Gains and Losses, Cancellation of Indebtedness, 66 Harv. L. Rev. 76r, 76r, 822 (1953).

${ }^{28}$ One additional aspect regarding statutory formulation may be mentioned. The ALI 1954 Draft Statute commenced experimentation with a separation of the statutory material between the everyday provisions and the special provisions. Thus, in the trust area it provided statutory demarcation between simple trusts and complex trusts, and in the partnership area between the rules applicable to ordinary partnership operations and those needed for complex partnership situations. This was followed in the trust area by the 1954 Code. This technique would seem useful in sharpening our perception of the basic framework by identifying the areas where considerable complexity is pretty mucil inevitable while at the same time keeping that complexity from interfering with an understanding of the underlying pattern. Here also further exploration of this device, and other techniques serving the same purpose, would seem helpful.
} 
draftsmen must work. These are conditions of speed and heavy load, with the work span severely truncated by the pressures for progress through the Congress of the legislation involved. The draftsmen are highly competent and skilled technicians, but they usually do not have the luxury of time for polish or even serious contemplation of alternative formulations. And so the work is done and the provisions are drafted. Hundreds of experts, and many nonexperts, representing the taxpayers affected will then pore over the initial version and seek flaws, ambiguities, less restrictive versions, expansion, or whatever suits the situation of each particular person, and the suggestions flow in. The draftsmen respond and the structure grows more technical and intricate. In general, the pattern here is that of experts speaking to experts, with the knowledgeable practitioners talking to the draftsmen in the stilted, artificial language that each understands well. But it is their language alone and not that of the less expert and uninitiated.

The greater part of the reason for the present manner of drafting, however, probably lies in a number of other factors that make for considerable detail and, indeed, in the advantages to be found in this approach. The important question is thus the consideration of the comparative advantages and disadvantages of the detailed approach to statutory drafting in contrast to a generalized approach. We may start with an enumeration of these advantages and disadvantages, and then consider some factors that bear on the necessary balancing.

\section{A. Detailed Statute}

The chief advantage of a detailed tax statute is that it provides certainty as to most of the matters covered by the detail. If one is willing to play by the draftsman's rules-to accept a highly technical, highly stratified arrangement under which a series of arbitrary definitions and terms are intricately interwoven-then the content of complex provisions can be pieced together and the answers to many, many questions will be found. It is not an easy game to play. It requires long practice, familiarity with the drafting techniques, and close and hard reading.

The detailed statute, however, despite its intricacy, is probably more satisfactory to tax lawyers and accountants simply because it furnishes the answers to many of their problems. Generalizations, though they be easier to read, are unsatisfactory to the tax advisor when the tax burden is an important one. Thus the I954 detailed treatment of the redemption of stock in section 302 is considerably more satisfactory to the tax advisor than the generalized phrase "essentially equivalent to a dividend" of the 1939 Code. Section 302, of course, generates its own uncertainties, but these are out on the periphery of the area while the uncertainties of the 1939 Code pervaded almost the entire area. Under section 302, the run-of-themill transaction, the everyday business arrangement, is dealt with in a manner that informs the parties what the tax consequences will be. In addition, if-and the "if" is important-the detailed statute is properly thought through and properly 
drafted, the result could be a reasonably coordinated solution to the problems of structure, both within each area and in the relationships among areas. The incorporation of a large amount of detail in the statute often almost forces a fairly intensive consideration of the structural problems.

Further, the answers provided by the detailed statute are legislative answers, and to many this is a factor of great importance. They see these answers as being nonpartisan, by which it is meant that the answers are not being provided by the administrators of the tax system but by the Congress. The answers are also provided quickly-here they are, right in the statute-and do not have to await case by case development. To a considerable extent, moreover, the particularity of the legislation is in response to the desire of interested members of Congress to have specific answers to the problems of their constituents that emerge during the legislative consideration of a bill.

But this certainty through legislative answers is bought at a serious price, for the disadvantages of the detailed tax statute are many. First, it creates its own problems of uncertainty. Each detailed rule produces its own statutory interpretation difficulties, and detail proliferates as more detail is added to settle the questions created by the earlier detail. Blind spots and arbitrariness at the borders of the detailed solution soon emerge, with consequent hardships and preferences, so that more detail is needed to correct the earlier deficiencies. But this needed interpretative and corrective detail can only be added by the legislature, because we are dealing in the realm of detailed legislative answers.

As a second problem, however, it is extremely difficult to provide the additional legislative detail that becomes necessary. The legislative process is slow and cumbersome. Congressional tax committees have many statutes and problems to consider, and correction of income tax statutory detail is usually far from being the first order of business. Moreover, as we have observed earlier, the legislative process involves the problems of pressure groups and the difficulties that lobbying brings. Many a tax preference can be hidden in a small, complex detail. Many a tax advantage can be won by pushing action on this detail to a priority status as against other details. The highly detailed tax statute crossed with the intricacies and subtleties of the legislative process is both a challenge and a temptation to the lobbyist. It is thus extremely difficult to keep a detailed tax statute current and under responsible control.

The detailed statute calls for extremely high drafting skills. In the search for detailed answers to all the problems that the drafting process discloses, the perspective may soon be lost. Even the details themselves are not likely to be well drafted. As a consequence of impatience or shortness of time, resort may too often be had to mathematical standards - this percentage, that period of time-because of the attraction of their "definiteness" without sufficient attention being given to the structural distortions which such answers can produce. Moreover, there is often no 
clue to whether a particularly difficult statutory stretch, one which doesn't seem to fit the logic of the over-all pattern, means what it appears to mean and properly so, or is instead a draftsman's error.

The consequences of this detailed drafting style are thus very often precision of detail but obscurity of over-all policy and intent. We see the trees and not the forest -indeed we often see trees, bushes, shrubs, and even tall grass and must work hard to distinguish among them. Without painstaking reconstruction of the pieces ourselves, we often cannot grasp the purpose and pattern of the statutory commands. The technical complexity of the drafting can thus become a barrier to the understanding of the structure as a whole.

Given such a detailed, often mathematically-oriented statute, it becomes impossible to fly by the seat of one's tax pants. Tax intuition and instinct are of no help in the face of myriads of rules turning on eighty per cent of this or that, one year from this or that date, this or that being done before this or that date, this or that attribution of stock ownership, and so on. Clearly, such "flyers" are passé under the present Code. While this is not a serious calamity, there is a need to provide working room for the use of tax instinct. An intelligent statutory structure makes it possible to rely on a well-trained tax instinct to provide the probable answers to the problems unforeseen by the draftsman. The able tax advisor can thus proceed to practice his profession with reasonable confidence. But a detailed statute that operates to submerge perspective and complicate the problems of structure through the deficiencies and arbitrary character of its drafting may not leave sufficient room for the proper play of tax intuition.

\section{B. The Generalized Statute}

$r$.

The above considerations are simply reversed when we consider the values and defects of the generalized statute. There is much less strain on the legislative process, since once the generalized legislative rules are provided, the rest is up to others. While high drafting skill is needed, it can be concentrated on furnishing the basic perspective and structure, leaving the details to others. Interpretation of a mass of detail, extreme use of mathematical certainty to cloak structural inconsistencies and inadequacies, intricate and wearying statutory provisions-all these disappear from the generalized statute.

But they do not disappear from the tax law. The generalized statute cannot banish the strain of implementing a modern income tax. It can only remove that strain from the legislature and place it on others. Under our present practices the strain would fall on the courts and the administrators to provide the answers that the statute no longer would furnish. But the problems of structure and the implementation of structure cannot be solved through piecemeal, case-by-case action. Thus, the courts were not working out the rules necessary to apply an "essentially equivalent to a dividend" test for stock redemption, which was the I939 Code test. 
A judge with only one facet of the problem before him in the particular case and having no real knowledge of the depth or scope of the underlying structural problem can hardly furnish the comprehensive standards needed to give meaning to that phrase. And administrators are not likely to do better if their response is to be given through isolated rulings, which are only informative and not authoritative, and case-by-case litigation strategy.

The result of a generalized statute, under our present practices, would thus be a tax law offering far fewer definite answers to day-to-day problems. The average tax lawyer would certainly feel the strain, for the rules would not be there to read but rather would have to be gleaned from the case law, that is, the common law of taxation, and in many instances simply guessed at. There is much more that he really would have to know, as a result. Business also would feel the strain, for it cannot tolerate too much uncertainty and too much delay in obtaining answers when the tax burden of a high rate statute is involved. A generalized statute would require more caution and less exploration of the precise location of tax boundary lines, which, while having some salutary aspects, would also present considerable difficulties. Also, in this setting, answers tend to be produced by negotiation and settlement, since only a limited number of cases can go to the courts. While some settlement activity is necessary, we must be wary that it does not become the rule and that the "bargain" does not become the principal device for settling tax liabilities.

\section{The Factors Relevant to Balancing the Advantages and Disadvantages of Statutory Detail Compared with Statutory Generalization}

There are thus advantages and disadvantages to be found both in the detailed statute and the generalized statute. Since choices must be made, the task becomes that of ascertaining the factors relevant to a balancing of these advantages and disadvantages.

\section{Attention to Equity}

As long as tax rates are reasonably high-and perhaps even with quite moderate rates-there will be a strong and appropriate insistence that the working out of the problems of structure be as fair as possible to the taxpayers affected. Much of our statutory detail arises from the feeling that this pressure for fairness shouldin fairness-be satisfied. The result is to place extreme emphasis on the details of our tax rules. Tax rules that are simple because they are arbitrary will not withstand this taxpayer pressure for fairness. The simple rule will give way to the complex as soon as the unfairnesses inherent in the simple rule are discerned and the pressure is exerted.

\section{Attention to Tax Avoidance}

On the other hand, again as long as tax rates-are high, there will be the same insistence that tax avoidance and tax manipulation be blocked: As soon as the 
simple answer is discovered to permit this or that "loophole," the insistence on preventing tax avoidance will demand complexity in the form of anti-tax-avoidance detail. In a sense this is an aspect of the demand for fairness-this time for fairness to the great mass of taxpayers as against the tax avoider.

The intensity of these demands for fairness-this taxpayer should not be hurt, that taxpayer should not be able to get this unwarranted benefit-is widely evident. It is comforting to some to say that to achieve less complexity we must accept some unfairnesses and rough spots, whether for or against the taxpayer. But when the die is cast on an important issue, no taxpayer group really works in this pious way. This is not said in criticism. We do place a high premium on fairness in our tax system-fairness both ways. In short, we take the equity of our income tax seriously-perhaps more seriously than any other country. But the income tax is by far our principal federal tax and we are able to devote considerable time and attention to it compared with countries which must manage both complex income tax structures and complex sales tax structures. We must of course strive for the most rational trade-offs between equity and less complexity, especially in dealing with provisions of wide scope. And we do-witness the standard deduction. But if the choice does become quite sharp, and serious unfairnesses can result, we will end up by avoiding that consequence even at a cost of greater complexity.

\section{Need for Answers}

In our complex society, an income tax involving high rates is tolerable only if the system supplies answers that are reasonably coordinated and are given with appreciable promptness. Taxpayers subjected to high rates will insist that the dayto-day workings of our society should be conducted in a setting under which the Government's share is known with reasonable certainty. The detailed statutory pattern of the I954 Code meets this need to a considerable extent. Hence those who have urged a return to the I939 Code or even earlier and simpler statutes are essentially seeking the wrong way out unless they can at the same time provide a mechanism other than the detailed statute to satisfy this need. The response that there is "no solution" to some tax problems and hence that we can have greater simplicity by forgetting about those problems is in essence close to nonsense and inadmissible. When a tax issue does arise, it must be solved and an answer must be given by somebody-administrator, court, tax advisor, or revenue agent. An answer does exist, and the questions really concern who provides the answer and when is it provided.

The frequency and insistency with which issues can arise in the tax field as compared with other fields of law are another reason why the "no solution, simple tax system" is only a simple illusion. Take the problem of whether a corporate obligation which in form appears to be a debt instrument is in reality an equity investment because of thin capitalization or other factors and ought to be so con- 
sidered. This issue can arise wholly apart from the tax law in a variety of corporation law issues-for example, is the holder of the obligation a creditor on a par with other creditors; is the corporation so thinly capitalized that it will be disregarded and the shareholders held liable for its debts? But the frequency with which these questions must be answered is very low, and there are thus relatively few nontax cases dealing with this problem. Contrast with this the number of litigated cases in the tax field in which this question has been faced. Obviously for a large group of corporations it must be answered as soon as the revenue agent picks up the tax return for audit. Corporation law can tolerate considerable uncertainty about this problem. The tax law sees it as an issue in which some guidelines are imperative.

\section{III}

\section{The Inevitability of Complex Detail and the Problem of the Effective Management of That Detail}

The conclusion seems inescapable that the federal income tax system will require and involve a large mass of complex detail. In fact, it appears that the larger the amount of sensible detail that is accumulated and properly organized, the more effective the system will be in view of its ability to provide definite answers with rapidity. There is little or nothing, therefore, to be gained by dwelling nostalgically on the past and enshrining the earlier revenue laws as models of perfection. The success some see of the "simple" law in a far less complex period is no guarantee of its success today, even if it was true then. And we really forget that what in retrospect appears "simple" to us now was quite complex in its time. Earlier decades also had their articles on simplification of the tax law.

In this light, the real question is that of the place of detail in the tax system. Which agency of government-the legislature, the administrators, the courts, or the tax advisors-is to develop the detail? Put differently, which agency is to have control over the management of complexity in the tax system-to furnish the detailed answers and to systematize the detail so that it is understandable and manageable? In effect, so put, the issue is one of the proper allocation of the tasks of furnishing solutions to tax questions. This question must be answered in the light of the uses of detail in a tax system. These uses are, as stated above, to furnish definite answers to the tax problems created by the day-to-day varying business and family transactions and to furnish those answers as rapidly as possible. The weaknesses in allocating too much of the task of solution to the legislature through the detailed statute have been explored. Likewise, the defects of taking the task away from the legislature through a generalized statute and then placing it in the courts have also been described. The possibility that remains to be considered is that of entrusting more of the task to the tax administrators. 


\section{A. The Suggestion That More Scope Be Given to the Treasury Department to Manage Tax Detail}

The suggestion here offered is premised on the conclusion, be it accepted with barely muffled longings for the past or frank recognition of the present and future, that our income tax system is not likely to be less complex and in all probability will steadily increase in complexity. This being so, it is suggested that it is appropriate to provide greater scope to the Treasury Department for the management of tax detail. That Department, with its policy guiding branch in the Treasury staff and its administrative branch in the Internal Revenue Service, is in reality the agency best suited to provide the needed effective control over tax detail.

In essence, the suggestion involves, first, a gradual shift from a highly detailed statute to more generalized provisions which would furnish the basic structure for the income tax. We should over a period of time select statutory areas for this process of change in which the suggested pattern could be developed. Under this pattern, the problems of structure would be answered in the statute with a degree of depth sufficient to provide over-all perspective and adequate guidance or standards for detailed implementation. Second, the suggestion involves clear delegation to the Treasury Department to amplify the statute through Regulations with details to whatever depth is determined to be necessary for effective operation of the statute in the particular area. These Regulations are to be authoritative; that is, they are to be binding unless shown to be clearly arbitrary. Their authoritative nature would in effect be such that only in rare cases would it be expected that the rule set forth in the Regulations is not to be accepted as the governing rule.

This combination of generalized statutory provisions and authoritative detailed Regulations would permit flexibility and promptness in providing the necessary tax detail. The basic premise, of course, is that complicated Regulations are far better suited to a proper ordering of the tax system than a complicated statute. If the regulatory detail first chosen develops interpretative uncertainties or borderline hardships and inadequacies or any other defects, the Regulations can readily be changed to meet the particular difficulties. At the same time, the Regulations lend themselves far more easily than a statute to drafting arrangements and improvements designed to provide the management of detail required to keep the detail comprehensible. In turn, the generalized statutory provision can itself more easily be altered when basic structural changes are required. The important issues will stand out more clearly and can be handled with better understanding by legislators and draftsmen.

This suggestion is not a novel one. Indeed, some of our present provisions operate in this fashion-for example, the consolidated return regulations-and operate successfully. The $x 969$ Act contains several provisions which move in this direction, 
such as the provision for regulatory authority in the debt-equity area ${ }^{20}$ and in the field of dividends of stock. ${ }^{30}$ The ALI Draft Statute contained a number of sections exemplifying this approach. What is suggested here in essence is that over a period of time we move in the direction of considerably more frequent use of this approach so that the Treasury is allocated more of the task of the management of tax detail.

\section{B. Some Problems of Implementation of the Suggestion-The Responsibilities That are Created}

The allocation here suggested of the tasks of furnishing solutions to the myriad of tax issues that daily arise is thus as follows: the furnishing by the Congress of the basic standards; the furnishing by the Treasury Department through Regulations of the authoritative extensive detail required for the implementation of those standards; and the furnishing by the courts, through the power of judicial review, of safeguards against extreme and arbitrary application of the statutory standards. All this would not occur overnight. It would instead be a gradual process of shifting, as we gain experience, in selected areas from the present system to that here suggested. The advantages of this suggested allocation seem clear, and its potentiality for the successful control of the necessary complexity appears greater than other possible arrangements. Yet there are significant questions respecting this allocation that must be faced. These questions cluster around the responsibilities that the suggestion would cast on the various agencies of government and groups involved in the income tax.

\section{x. The Responsibilities of the Treasury Department}

Can the Treasury Department fulfill its responsibilities under this allocation? The chief responsibilities would be, first, an attitude of intelligent fair-mindedness in the exercise of the authority granted to it, so that the decisions of the Treasury made in this regulatory function rise above the partisan context of the administrative activities exercised in audit, settlement, and litigation, and, second, high technical competence in the formulation of the Regulations, both as to substance and drafting. Obviously, these responsibilities demand a high caliber of personnel and an awareness of all that is involved in fulfilling the role assigned to the Treasury. But there is no reason why a Treasury Department cannot meet these responsibilities-indeed it has met responsibilities of this character successfully-or cannot rise to them if one feels that as customarily staffed and structured the Treasury could not meet those demands. In essence, the problem is not whether the Treasury can fulfill this role, but rather, what is necessary to enable the Treasury to perform the task with competence. In this light, attention must be paid to personnel, to organization, to procedures for the promulgation and constant review of Regulations, to the gathering

${ }^{29}$ Tax Reform Act of 1969, $\$ 415$, adding CODE $\$ 385$.

${ }^{80}$ Tax Reform Act of $1969, \S 42 \mathrm{r}$, amending CODE $\$ 305$. See specifically new $\$ 305(\mathrm{c})$. 
of the necessary background information, and to hearings on Regulations and the like.

We must not overlook the fact that the growth of the present ruling practice of the Internal Revenue Service, operating under policy guidance by the Treasury, has meant entrusting a great deal of discretion to the Treasury and the Service. Of course, an adverse answer on a request for a ruling does not bar the taxpayer from going ahead with his plan and litigating the issue if necessary. But a great many taxpayers will not proceed without a favorable ruling, so that the Treasury Department and the Service today in effect have allocated to them extensive responsibility. Yet tax lawyers in the large appear to favor this ruling practice and also appear to regard the administrative discretion as being properly exercised on the whole.

It must also be remembered that interpretative issues will arise under authoritative Regulations-what do the Regulations mean?-and these issues will go to the courts. Hence once such an issue has arisen in a particular case where the transaction has occurred, the taxpayer has the protection of resort to the courts. The importance of the issue for the future can be eliminated through prospective change in the Regulations, so that interpretative doubts need not cloud the future as they do today. Thus, over-all certainty is provided, while fairness in the application of Regulations to past transactions is also maintained.

\section{The Responsibilities of the Congress}

Can the Congress fulfill its responsibilities under this allocation? The larger question here is whether the Congress would permit the judgments of the Treasury in furnishing implementing detail through Regulations to stand despite the pressures for change that unhappy taxpayers or groups will exert. Today, because we have a detailed statute and the Congress has taken over the responsibility for detail, most of the focus of taxpayer pressures for changes in that detail is on the Congress. The Congress is thus in the habit of endless involvement with tax detail. There are also, for many legislators, important advantages in exercising this power over detail. But since the essence of the suggestion here made is that gradually this function be shifted to the Treasury, the Congress would have to acquire new habits in the tax field. It would have to be content to let the machinery of detail be handled by the Treasury and instead concern itself with the task of seeing what is needed in basic guidance to enable the Treasury to exercise that function. Certainly the Congress should not require that its Committees or their tax staffs formally review and approve the Treasury Regulations before they are promulgated. Such a step tends to be the worst of all worlds, for no one knows where responsibility really lies and a strong-minded legislator single-handed can cause much mischief, since neither the full legislative process nor the full administrative process would be operative. This is not to say there should not be consultation of an informal sort 
with the tax staffs of the Congress, since that form of interplay can be helpful, given the proper approach on each side.

\section{The Responsibilities of the Courts}

Can the courts fulfill their responsibilities under this allocation? Here the issue, as in the case of the Congress, is whether the courts would recognize that more of the management of tax detail has been delegated to the Treasury Department. This means that the courts would have to accept the Treasury Regulations as the authoritative standards, except in rare instances. The issues before the courts would largely be those of the interpretation of the Regulations when applied to the particular cases before them, rather than the passing of judgments on the validity of the rules established by the Regulations. Obviously, if the Regulations can be set aside as easily as the present Regulations are treated by some courts, the basic premise of the suggestion would be altered. For then the management of detail will have been shifted from the Congress to the courts, and the latter, as earlier indicated, are not in a position efficiently to carry out such an assignment. The present approach of the Supreme Court to tax regulations is closer to the mark, but here, too, the temptation to substitute the court's judgment for that of the administrator must be repressed.

\section{The Responsibilities of the Legislative Draftsmen}

Can the legislative draftsmen fulfill their responsibilities under this allocation? This is solely a matter of the technical competence necessary to the drafting of generalized statutory provisions and of the time required to use that competence. The legislative draftsmen working in the tax field will have to perfect a new technique, that of presenting the principles basic to the particular statutory structural solution and sufficient in structural framework, so that the Treasury will be adequately guided in its implementation of the statutory provision. Such drafting requires that the structural problems be carefully thought through, which in turn means that prior research and discussion of the structural difficulties are highly important. The draftsmen will have to present statutory standards that offer real guidance, yet stop short of being enmeshed in detail.

\section{The Responsibilities of the Tax Profession}

Can the tax profession fulfill its responsibilities under this allocation? Here, as in the case of Congress and the courts, the tax profession-which includes lawyers, accountants, and other professionals engaged in the tax process-would also have to recognize the delegation to the Treasury Department to provide authoritative detail. In essence what is needed is a willingness to view the tax system as a whole and with the necessary degree of realism. That system is capable of generating an enormous number of questions that divide taxpayer and government over particular 
issues-issues that are narrow, technical, and not of transcendental importance. But society cannot afford to allow too much of the time and brains of its ablest members to be consigned to that task. After all, tax lawyers are fond of pointing out that one must be a bit smarter, must be an abler lawyer, to practice as a tax lawyer, as compared with other specialities of the law. Nevertheless, answers to the countless minor tax questions must be provided, promptly and with reasonable certainty, if the tax system is to work with the necessary degree of efficiency that society is entitled to demand. The tax bar must be sufficiently realistic to recognize that the Treasury Department is better positioned to manage the necessary tax detail than the legislator or the judge. It would have to be willing therefore to accept the gradual assignment of that role to the Treasury and willing to rely on the preservation of the right to challenge Treasury Regulations as arbitrary as sufficient to keep those Regulations within broad but acceptable bounds. This done, the tax bar must then work out the ways in which it can best assist the Treasury in perceiving and understanding the issues which the tax bar believes are present in the formulation of the necessary detail in any particular situation and in intelligently determining the solution to those issues to be adopted in Regulations. ${ }^{31}$

\footnotetext{
${ }^{31}$ Two other matters of implementation may be raised. One relates to the appropriateness of adopting a generalized anti-tax-avoidance statutory provision. We have today a number of anti-tax-avoidance statutory sections, the most general of which are CODE $\$ 269$, relating to the acquisition of corporations, and CODE $\S_{4} 82$, relating to businesses under common control. Other provisions turn with minor variations in detail on a purpose or intent to avoid taxes-e.g., CODE $\$ \S 367,532$, I55 I. Hovering over the entire statute are the judicial anti-tax-avoidance doctrines, again expressed with variations in phrasing or emphasis-the "business purpose" requirement of Gregory v. Helvering, 293 U.S. 465 (1935), the "sham" characterization of Knetsch v. United States, 364 U.S. 36r (rg60). The task thus is to see if these various barriers to tax avoidance can be presented in a single formulation which will operate as a guiding principle for the entire statute and whether the result is an improvement. It is clear that all of these barriers today save the tax system from the far greater proliferation of detail that would be necessary if the tax avoider could succeed merely by bringing his scheme within the literal language of substantive provisions written to govern the everyday world. If those substantive provisions, be they in statute or regulations, must in addition be written also to forestall the distortions that the tax schemer can produce, then here again society will be yielding too much of its brains to the process of revenue collection. The point can be put the other way around. Anti-tax-avoidance measures are necessary to back up the fair-minded, conservative tax advisors who keep the system functioning by turning their backs-or really their clients' backs-on the many tax avoidance schemes that travel around. Unless the soundly grounded tax advisor is protected in his advice by administrator and courts, he in the end will have to succumb to playing the tax avoider's game, and indeed to playing it much more ably. We should in this regard study the history of Cone $\$ 367$. To what extent has it, for example, permitted the Service to cope with the tax avoidance that inevitably comes with tax sophistication? Has it provided the necessary flexibility to accommodate the proper desires of taxpayers? How much more complex would the Code be in its absence? Are there ways in which the operation of this unique device can be improved?

The second matter, reflecting our concern for fairness, is the other side of the tax coin, that of relief against tax hardships. The wheels of the tax system of necessity grind exceedingly small, and at times they function with unintended and severe hardship in particular cases. Today the only way to relief in most situations is through legislative mercy, cast in the form of special amendments to the Code-and often disguised or camoullaged. But, as is obvious by now, this is an unsatisfactory solution and the task is thus to find more efficient mechanisms. A recent statement by Senator Kennedy in connection with the Tax Reform Act of 2969 graphically and carefully illustrates this problem. See II5 Conc. Rec. Si6,099-r22 (daily ed. Dec. 8, 1969). To a considerable extent, of course, the flexibility
} 


\section{ConcLusion}

In summary, we start with the recognition that our present federal tax system, especially the income tax, is today an exceedingly complex structure. In seeking the causes of that complexity we find that a significant source of complexity lies in two basic facts-that an income tax of broad coverage is inherently a quite complicated tax, and that this is especially so in the stage of development reached by a country the size of the United States. These causes cannot be altered. Looking further, we find that certain of the basic substantive concepts and approaches now utilized in our income tax are also a significant source of complexity. Chief among these are the preferential treatment of capital gains and losses, existence of the corporate tax and the separate treatment of corporations and shareholders alongside a desire to minimize the tax consequences of that separate treatment in a number of situations, and the existence of high rates and a progressive rate structure for the individual income tax. It is not likely that these will be radically altered in the years ahead-nor is it clear that a turn to different basic concepts would be a simplifying move. We also have found that our income tax structure contains an elaborate and complex tax expenditure apparatus interwoven with the regular income tax. While the over-all trend, despite unfortunate retrogression here and there, seemsperhaps-to be in the direction of reducing this apparatus, the process of this change could well mean increasing complexity in some cases. The complexity which all these various sources produce is in turn amplified by the tendency of that complexity to generate still greater complexity as a consequence of the inevitable workings of a tax system. Finally, we have observed that many aspects of the process of development of tax policy operate to increase the inherent complexity of the income tax structure. There are some counterbalancing factors operating in the direction of less complexity, at least in the steps needed to keep a mass tax administratively operable. And some progress, at least toward better understanding, can be achieved through increased research in the problems of tax structure. At the very least that research would enable us to comprehend the structural causes of complexity and the paths that may be open to more appropriate solutions to the major problems of structure.

The inescapable conclusion from this survey of the causes of our present tax complexity is that a very large amount of complexity is inevitable, and that the

afforded through the suggested handling of detail in authoritative regulations would here lessen the strain. For once the defect is perceived, a better rule can readily be written for the futurc, and cven for the past in many cases through the power to make regulations retroactive in favor of the taxpayer. But some cases of hardship will always remain-the wrong election, the missed date, the unnecessarily severe detail as applied to these facts. Here also thought and research may provide a solution. Perhaps a hint of the trail lies in a little-noticed present provision of the Regulations, $\$ 1.9100-x$, under which the Commissioner has authority for good cause shown to extend the time fixed by any income tax regulation for the making of an election by a taxpayer, including the power to do so even after the election date has passed. Maybe this Regulation could be expanded to cover other matters besides elections. Perhaps another trail lies in the direction of a Congressional special relief bill procedure similar to that now utilized for relief bills in other fields. 
degree of the complexity will probably increase rather than decrease. The solution thus does not lie in any "simplification" of the tax law. Nor does it lie in a nostalgic search for the "simpler" Internal Revenue Code that is simpler solely because it avoids many of the structural problems that require an answer. The challenge of the future in the tax field is not the attainment of such simplification. Rather, the challenge lies in finding the most efficient way for the management of tax complexity.

We must recognize the vast coverage of the income tax and its enormous capacity for generating countless minor questions. These conditions demand a tax system that provides the answers to those questions with the maximum possible efficiency. This means a system that furnishes a very large amount of certainty through sufficient flexibility to produce with promptness definite answers to new questions as they arise. But at the same time the mechanism used must have the elements of fairness required to make it acceptable within our prevailing concepts of government. All this, however, adds up to a system involving a very large amount of tax detail. This detail must be effectively developed and organized. It must be capable of reasonably prompt change when the need for change becomes clear. In short, this detail must be efficiently managed.

Today the task of managing tax detail has to a very considerable extent been allocated to the Congress, as is manifested by our present highly particularized, intricate Code. But the inefficiency inherent in this allocation is increasingly being recognized. Legislative detail is often inadequately developed and confusingly presented. More important, it cannot be altered with the necessary flexibility. Unsatisfactory and unclear detail must thus continue to exist and govern transactions long after the inadequacies have become apparent. Nor can the management of detail be allocated to the courts. The judicial system, involving case-by-case results, cannot provide the coordinated implementation that is needed, nor can it operate with the required speed. This is especially so under our present complicated judicial system for the adjudication of tax controversies.

The suggestion here advanced to meet the challenge of the effective management of detail is that gradually more of the task be allocated to the Treasury Department. The mechanism suggested is that of gradual change in various areas to more generalized statutory provisions which develop the structural patterns and framework. This development would possess that degree of definiteness which would enable the Treasury in turn to implement the statutory framework with the necessary detail. That detail would be provided through authoritative Treasury Regulations that would be binding, subject only to being set aside by the courts as arbitrary. It would be expected that such Regulations would be set aside only in rare situations. This management of detail through the Regulations would permit the development of detail to the depth necessary to provide the requisite certainty, along with the supplementary public and private ruling process. It would also afford 
the appropriate flexibility in changing unsatisfactory detail and in developing new detail when required.

Necessarily the suggested course requires that the Treasury Department possess the skills and integrity essential to achieve acceptance of its role as the manager of detail. At the same time it requires that the Congress, the courts, and the tax bar respect this responsibility so allocated to the Treasury Department. The Congress must thus turn its attention to the legislative problems involved in formulating and maintaining generalized statutory provisions in place of present detailed provisions. The courts must turn to the task of adjudicating tax disputes which to a considerable extent will involve interpretations of Regulations rather than of statutory provisions. It is also in order to re-examine our complex judicial system for the adjudication of tax controversies to see if a more efficient system can be devised. The tax profession must turn to the consideration of procedures that will aid the Treasury Department in carrying out its responsibilities in a way that combines the obtaining of the necessary information with the ability to reach conclusions in difficult and confused situations and then to present those conclusions in understandable, cohesive patterns.

Our federal income tax must perform a very large and important task. The revenues it is called upon to furnish are huge in amount. Those revenues must be raised efficiently, so that as each year recedes into the past the system can function all over again for the next year. The amounts must also be raised fairly, so that the taxpayers will fulfill their task of voluntary self-assessment and payment. Our society must perforce assign a share of its available talent to the task of keeping the tax system working efficiently. But talent is limited and a tax system that absorbs an undue proportion of brains and time becomes suspect. As with many other aspects of our complex society, the major task in our tax system today is to find an acceptable way to manage the complexity that is inevitable. 